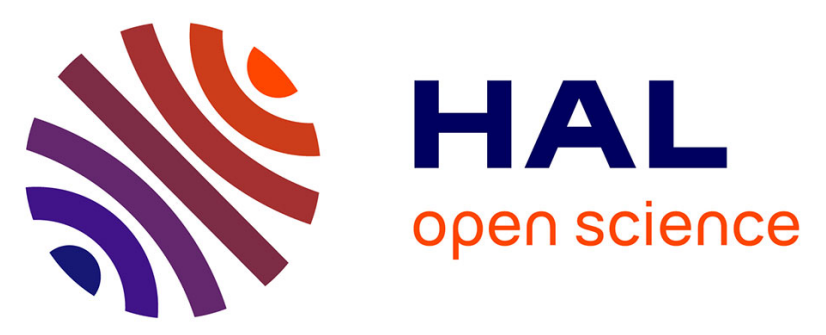

\title{
Supercritical CO2 extraction of Tetraclinis articulata: chemical composition, antioxidant activity and mathematical modeling
}

\author{
Nejia Herzi, Séverine Camy, Jalloul Bouajila, Philippe Destrac, Mehrez
}

Romdhane, Jean-Stéphane Condoret

\section{To cite this version:}

Nejia Herzi, Séverine Camy, Jalloul Bouajila, Philippe Destrac, Mehrez Romdhane, et al.. Supercritical $\mathrm{CO} 2$ extraction of Tetraclinis articulata: chemical composition, antioxidant activity and mathematical modeling. Journal of Supercritical Fluids, 2013, vol. 82, pp. 72-82. 10.1016/j.supflu.2013.06.007 . hal-00881074

\section{HAL Id: hal-00881074 \\ https://hal.science/hal-00881074}

Submitted on 7 Nov 2013

HAL is a multi-disciplinary open access archive for the deposit and dissemination of scientific research documents, whether they are published or not. The documents may come from teaching and research institutions in France or abroad, or from public or private research centers.
L'archive ouverte pluridisciplinaire HAL, est destinée au dépôt et à la diffusion de documents scientifiques de niveau recherche, publiés ou non, émanant des établissements d'enseignement et de recherche français ou étrangers, des laboratoires publics ou privés. 


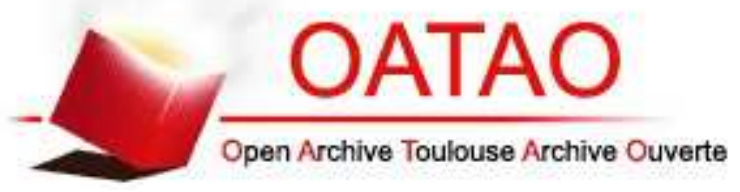

\section{Open Archive Toulouse Archive Ouverte (OATAO)}

OATAO is an open access repository that collects the work of Toulouse researchers and makes it freely available over the web where possible.

This is an author-deposited version published in: http://oatao.univ-toulouse.fr/ Eprints ID: 9928

To link to this article: DOI:10.1016/j.supflu.2013.06.007

http://dx.doi.org/10.1016/j.supflu.2013.06.007

\section{To cite this version:}

Herzi, Nejia and Camy, Séverine and Bouajila, Jalloul and Destrac, Philippe and Romdhane, Mehrez and Condoret, Jean-Stéphane Supercritical CO2 extraction of Tetraclinis articulata: Chemical composition, antioxidant activity and mathematical modeling. (2013) The Journal of Supercritical Fluids, vol. 82. pp. 72-82. 


\title{
Supercritical $\mathrm{CO}_{2}$ extraction of Tetraclinis articulata: Chemical composition, antioxidant activity and mathematical modeling
}

\author{
Nejia Herzi ${ }^{\mathrm{a}, \mathrm{b}}$, Séverine Camy ${ }^{\mathrm{b}, *}$, Jalloul Bouajila ${ }^{\mathrm{c}, * *}$, Philippe Destrac $^{\mathrm{b}}$, \\ Mehrez Romdhane ${ }^{\mathrm{a}}$, Jean-Stéphane Condoret ${ }^{\mathrm{b}}$ \\ a Unité de recherche MACS, ENIG, Route de Médenine, 6029 Gabès, Tunisia \\ ${ }^{\mathrm{b}}$ Université de Toulouse, INPT, UPS, Laboratoire de Génie Chimique UMR CNRS 5503, 4, Allée Emile Monso, F-31030 Toulouse, France \\ c Université de Toulouse, Laboratoire des Interactions Moléculaires et Réactivité Chimique et Photochimique UMR CNRS 5623, Université Paul-Sabatier, 118 \\ route de Narbonne, F-31062 Toulouse, France
}

Keywords:

Supercritical carbon dioxide extraction

Tetraclinis articulata

Essential oil

Antioxidant activity

Modeling

\begin{abstract}
A B S T R A C T
Operating conditions for extraction from the leaves of Tetraclinis articulata using supercritical carbon dioxide $\left(\mathrm{SCCO}_{2}\right)$ were studied to focus on the feasibility of obtaining volatile and nonvolatile fractions through the use of different extraction pressures (90, 280 and 1000 bar). In addition, influence of temperature, static pretreatment and dynamic extraction durations, particle size and $\mathrm{CO}_{2}$ flow rate were investigated. All extracts were analyzed by GC-FID/MS and their antioxidant activity was measured using ABTS ${ }^{\bullet+}$ and $\mathrm{DPPH}^{\bullet}$ methods. Conventional hydrodistillation (HD) was also performed for comparison. At high $\mathrm{CO}_{2}$ pressure (280 and 1000 bar), the amount of phenolics in the extracts was higher (respectively 102.03 and $267.90 \mathrm{GAE} \mathrm{mg/g}$ ) than for HD and supercritical fluid extraction (SFE) at 90 bar (respectively 8.89 and $9.70 \mathrm{GAE} \mathrm{mg} / \mathrm{g}$ ). Correlatively, high antioxidant activity was found for high pressure SFE. Surprisingly, for extracts obtained by SFE at 90 bar, despite very low phenolic content, significant antioxidant activity was observed, while essential oil obtained by HD, which presented also low phenolic content, exhibited low antioxidant activity.

Physical aspects were only investigated for the low pressure supercritical extraction (90 bar) process. Qualitative assessment of kinetic curves together with their modeling revealed that the extraction process was mainly limited by the thermodynamic equilibrium of easily accessible solutes but where axial dispersion was significant. From this result a simple extrapolation procedure was proposed.
\end{abstract}

\section{Introduction}

In the last 20 years, research upon natural substances such as aromatic and medicinal plants has concentrated on two primary areas: identification of their biological activity (such as antioxidant activity) and development of novel extraction methods insuring better quality and eco-friendly operation. In this work, the Tetraclinis articulata specie will be investigated in respect to both these aspects.

T. articulata belongs to the family Cupressaceae and is a native plant of the south-western Mediterranean, mainly North Africa. It is an important element of the Maghreb vegetation (Morocco, Algeria and Tunisia). This plant is a widely distributed tree in North Africa where it covers a total area of $10,000 \mathrm{~km}^{2}$ [1]. T. articulata

\footnotetext{
* Corresponding author. Tel.: +33 534323713.

** Corresponding author. Tel: +33 562256885.

E-mail addresses: severine.camy@ensiacet.fr (S. Camy), jalloul.bouajila@univ-tlse3.fr (J. Bouajila).
}

is known as a high quality health food which is commonly used in Tunisian traditional medicine. It has been found to have pharmacological effects, including antioxidant activity that may explain the benefits in treating circulatory disorders perceived from the use of this herb over the centuries. It is mainly used against childhood fevers, respiratory and intestinal infections, stomach pain, diabetes and hypertension [2]. Therefore, it is interesting to find an effective method for isolation of bioactive compounds from $T$. articulata.

It is known that the isolation of natural antioxidants is difficult because most of them are heat-sensitive and volatile in steam, and can be therefore destroyed when a nonadapted extraction process is used [3]. Traditionally, extraction of bioactive compounds from plants is performed by steam distillation, hydrodistillation (HD) or organic solvent extraction [4,5]. Using these techniques, long extraction time, toxic solvent residues, labor-intensive operation and degradation of thermo-sensitive compounds are usually observed. Such disadvantages can be avoided by using the supercritical carbon dioxide $\left(\mathrm{SCCO}_{2}\right)$ technique [6,7]. Indeed, this technique, more generally referred as supercritical fluid extraction (SFE), should improve the volatile oil quality by avoiding any 
thermal stress to the volatile component. The solvent power of $\mathrm{SCCO}_{2}$ is directly related to its density. So, choice of the values of operating pressure and temperature is a critical step in the development of an efficient process. These operating variables determine the value of the density and consequently the extract yield and composition, and, therefore, the functional properties $[8,9]$ of the extract. Also, other factors such as duration of the static and dynamic periods of extraction, particle size and solvent flow rate can influence the process performance [10], and must be investigated.

In the literature, to our knowledge, very few studies were performed on T. articulata. As an example, Rached et al. [11] presented results obtained from a plant from Algeria harvested in April 2008. But, up to now, no study on the SFE extraction of $T$. articulata from Tunisia has been reported in the literature. However, very numerous works have studied the extraction of volatile oil from other plants using $\mathrm{SCCO}_{2}[6,7,12,13]$. For example, extraction of the volatile oil from Salvia officinalis has been studied by several authors (Reverchon et al. [14], Aleksovski and Sovová [15], Glisic et al. [16]) who used the same extraction conditions to recover volatile oils (pressures between 80 and 130 bar, temperatures between 40 and $60^{\circ} \mathrm{C}$ and solvent flow rates between 5 and $30 \mathrm{~g} / \mathrm{min}$ approximately). Only the method proposed by Reverchon et al. [14] differed from the fact that they carried out the separation of the extracts using two separators at different conditions, which yielded absence of waxes in the collected volatile extract.

The objective of the present work was to evaluate the extracting capacity of $\mathrm{SCCO}_{2}$ to obtain $T$. articulata volatile oil with possibly different properties and to investigate the effect of the extraction conditions. It is suspected that the volatile fraction could be selectively isolated at low pressure extraction, whereby the pressures between 100 and 1000 bar would be more favorable for obtaining fractions containing heavier compounds with high antioxidant characteristics. To check these assumptions, extractions were performed at pressures 90, 280 and 1000 bar and temperatures equal to 40 and $60^{\circ} \mathrm{C}^{-\mathrm{CO}_{2}}$ flow rate was varied between 5 and $20 \mathrm{~g} / \mathrm{min}$, and different mean particle sizes so as different extraction durations were tested. In this work comparison with extracts obtained by HD was also proposed.

On account of importance of SFE for industrial application, extrapolation of laboratory experimental data is necessary and requires extensive knowledge of the physical phenomena occurring during the course of the extraction. Then the use of mathematical models allows giving the extrapolation rules. Especially, for extrapolation purposes, it is of great interest to identify whether the extraction process is limited by mass transfer phenomena or by thermodynamics. Such information can be obtained from the study of extraction kinetics and their modeling using mathematical models proposed in the literature [17].

\section{Materials and methods}

\subsection{Plant material}

Leaves from cultivated plants of T. articulata were collected by hand during October 2010 (in the morning) from the same location, Korbos, located in the region of Cap Bon at 60 kilometers from Tunis (latitudes $36.82 / 36^{\circ} 49^{\prime} 44^{\prime \prime}$ and longitudes $10.59 / 10^{\circ} 35^{\prime} 36^{\prime \prime}$ ), Tunisia. Harvested material was dried in the air, protected against direct sunlight, until a constant weight was achieved. The average particle size of $T$. articulata, was obtained after sieving of grinded leaves (using laboratory knife grinder). The moisture content of the air-dried plant material, determined by the Karl Fischer volumetric titration, was $9 \%(\mathrm{w} / \mathrm{w})$. The efficiency of the different extraction processes is assessed using the extraction yield, defined as the mass of collected extract divided by initial mass of wet plant material ( $9 \%$, $\mathrm{w} / \mathrm{w}$ moisture content).

\subsection{Chemicals}

All chemicals were of analytical reagent grade. All reagents were purchased from Sigma-Aldrich-Fluka (Saint-Quentin, France). Commercial carbon dioxide (99.99\% purity) was purchased from Air Liquide (Bordeaux, France) for the extraction of volatile and nonvolatile components by SFE process.

\subsection{Supercritical fluid extraction (SFE)}

Supercritical extractions were carried out using two different devices. The first one termed SF200 extraction pilot unit, from Separex Chimie fine, (France) is described elsewhere [18,19]. Briefly, this apparatus is composed of a $113 \mathrm{~mL}(16 \mathrm{~cm}$ height and $3 \mathrm{~cm}$ internal diameter) tubular extractor ( 300 bar max) with a cascade of three $15-\mathrm{mL}$ cyclonic separators connected to the extractor outlet.

In the present study, the $113 \mathrm{~mL}$ stainless steel extractor was loaded with $50 \mathrm{~g}$ of dried $T$. articulata leaves with an average particle size of $1.5 \pm 0.3 \mathrm{~mm}$. The system was operated at a temperature between 40 and $60^{\circ} \mathrm{C}$ and pressure of 90 bar for volatile fraction extraction. Pure $\mathrm{CO}_{2}$ was passed into the cell with the flow rate kept between 5 and $20 \mathrm{~g} / \mathrm{min}$ in all runs.

The second apparatus, termed A21 (SFE1000 bar), from Separex Chimie fine, France, is composed of a $63 \mathrm{~mL}$ tubular extractor which can be operated up to 1000 bar and $200^{\circ} \mathrm{C}$. Only one separator is connected to the extractor outlet. Pressure in the extractor is adjusted by a backpressure regulator. In this work, the extractor was loaded with $28 \mathrm{~g}$ of dried $T$. articulata leaves with an average particle size of $1.5 \pm 0.3 \mathrm{~mm}$. The system was operated at 280 and $1000 \mathrm{bar}, \mathrm{CO}_{2}$ flow rate of $20 \mathrm{~g} / \mathrm{min}$ and two temperatures, 60 and $40^{\circ} \mathrm{C}$.

Density of the solid phase has been experimentally determined and is equal to $\rho_{S}=815 \mathrm{~kg} / \mathrm{m}^{3}$. The bed void fraction was estimated by $\varepsilon=1-\rho_{a} / \rho_{s}=0.4575$ where solid apparent density is obtained with $\rho_{a}=m_{0} / V_{\text {extr }}\left(\rho_{a}=442 \mathrm{~kg} / \mathrm{m}^{3}\right)$ where $m_{0}$ is the initial mass of plant material.

\subsection{Hydrodistillation}

A conventional method of HD was carried out to compare the extraction performances with SFE. This set-up was composed of a 2L boiler, a condenser and a measuring tube with a stopcock. A return tube for the aqueous part of the distillate allowed the cohobation technique to be used. Dried leaves of T. articulata (100 g), ground at diameter $1.5 \mathrm{~mm}$, were placed in a Clevenger apparatus and mixed with distilled water at a ratio of $1 / 10$ (plant material/water). After 180 min (corresponding to the duration when no more essential oil was obtained at the condenser), the essential oil was collected, dried over anhydrous sodium sulfate and stored at $4{ }^{\circ} \mathrm{C}$ in the dark until used.

\subsection{Chemical components analysis: GC-FID and GC-MS}

Quantitative and qualitative analysis of the volatile oil was carried out by gas chromatography-flame ionization detection (GC-FID) and gas chromatography-mass spectrometry (GC-MS). Gas chromatography analyses were performed on a Varian Star 3400 Cx chromatograph (Les Ullis, France) fitted with a DB5MS fused silica capillary column (5\% phenylmethylpolysyloxane, $30 \mathrm{~m} \times 0.25 \mathrm{~mm}$, film thickness $0.25 \mu \mathrm{m}$ ). Chromatographic conditions were a temperature rise from $60^{\circ} \mathrm{C}$ to $260^{\circ} \mathrm{C}$ with a gradient of $5^{\circ} \mathrm{C} / \mathrm{min}$ and then $15 \mathrm{~min}$ at $260^{\circ} \mathrm{C}$. A second gradient of $40^{\circ} \mathrm{C} / \mathrm{min}$ was applied to reach $340^{\circ} \mathrm{C}$. Total analysis duration was $57 \mathrm{~min}$. For 

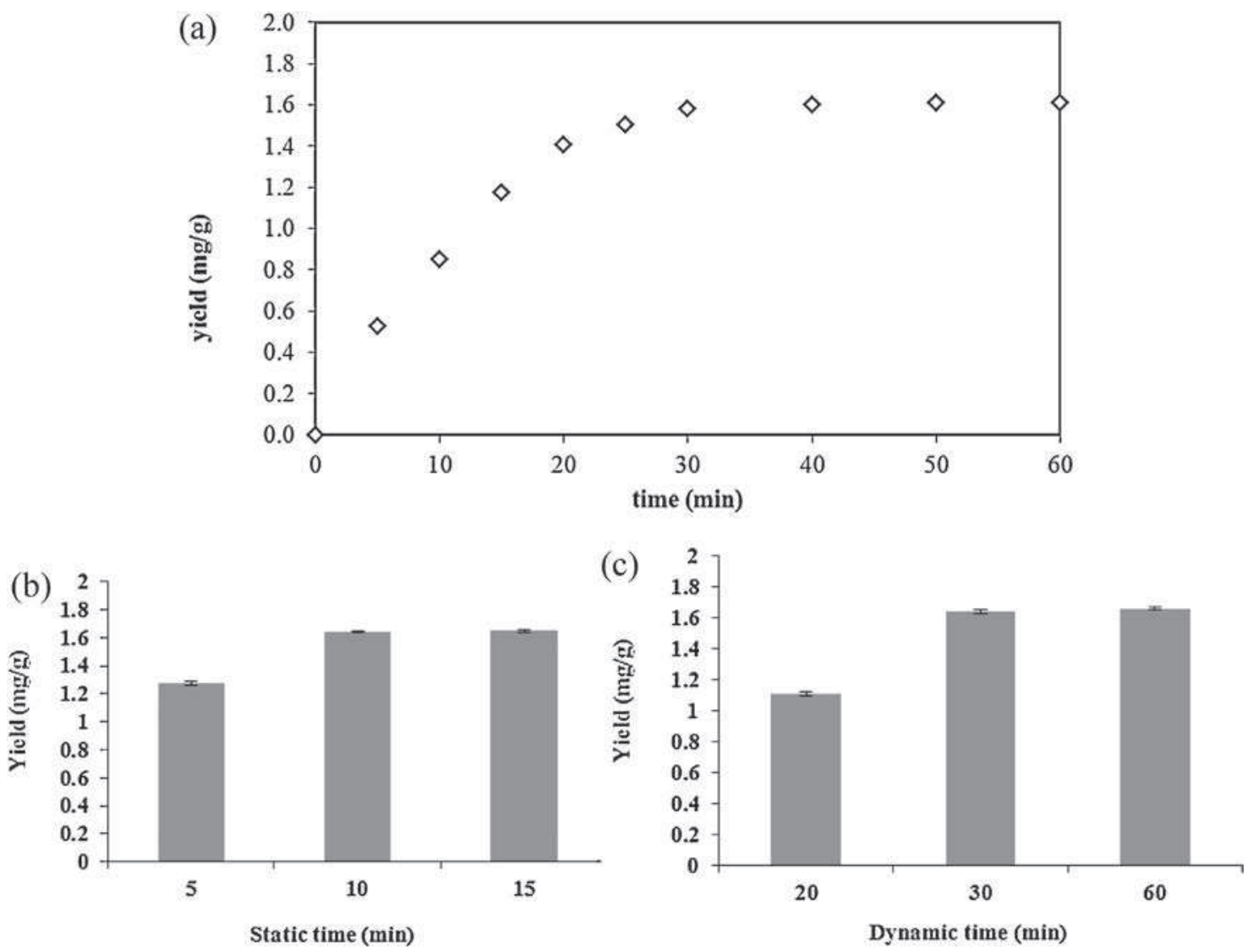

Fig. 1. SFE yield of volatile oil from $T$. articulata at $W_{\mathrm{CO}_{2}}=20 \mathrm{~g} / \mathrm{min}, P=90$ bar and $T=40^{\circ} \mathrm{C}$. (a) Kinetics of the extraction process, (b) influence of static period duration (followed by $30 \mathrm{~min}$ of dynamic extraction) and (c) influence of dynamic extraction duration (with a static period of $10 \mathrm{~min}$ ).

analysis purposes, the volatile oil was dissolved in petroleum ether. Samples $(1 \mu \mathrm{L})$ were injected in the split mode at a ratio of $1: 10$ Helium (purity 99.999\%) was used as the carrier gas at $1 \mathrm{~mL} / \mathrm{min}$. The injector was operated at $200^{\circ} \mathrm{C}$. The mass spectrometer (Varian Saturn GC-MS-MS 4D) was adjusted for an emission current of $10 \mu \mathrm{A}$ and electron multiplier voltage between 1400 and $1500 \mathrm{~V}$. The temperature of the trap was $150^{\circ} \mathrm{C}$ and that of the transfer line was $170^{\circ} \mathrm{C}$. Mass scanning was from 40 to $650 \mathrm{amu}$.

Compounds were identified (i) by comparison of their retention index (RI), obtained on a nonpolar DB-5MS column relative to $\mathrm{C}_{5}-\mathrm{C}_{24} \mathrm{n}$-alkanes, with those provided in the literature, (ii) by comparison of their mass spectra with those recorded in NIST 08 (National Institute of Standards and Technology) and reported in published articles, (iii) by co-injection of available reference compounds. The samples were analyzed in duplicate. The percentage composition of the volatile oil was calculated by the normalization method from the GC peak areas, assuming identical mass response factors for all compounds. Results were calculated as mean values after two injections of volatile oil, without using correction factors. The identification is only made for the volatile compounds. Especially, for SFE extracts, some nonvolatile compounds cannot be identified. The detection limit is $0.1 \mathrm{mg} / \mathrm{L}$ while the quantification limit is $1 \mathrm{mg} / \mathrm{L}$.

\subsection{Determination of total phenolic content}

The phenolic contents of extracts were determined by the Folin-Ciocalteu method [20]. A diluted solution of each extract $(0.5 \mathrm{~mL})$ was mixed with the Folin-Ciocalteu reagent $(0.2 \mathrm{M}$, $2.5 \mathrm{~mL}$ ). This mixture was kept at room temperature for $5 \mathrm{~min}$ and then a sodium carbonate solution $(75 \mathrm{~g} / \mathrm{L}$ in water, $2 \mathrm{~mL})$ was added.
After $1 \mathrm{~h}$ of incubation, the absorbance was measured at $765 \mathrm{~nm}$ against water blank. A standard calibration curve was plotted using gallic acid (0-300 mg/L). The results were expressed as $\mathrm{mg}$ of Gallic Acid Equivalent (GAE)/kg of plant material.

\section{7. $\mathrm{DPPH}^{\bullet}$ free radical scavenging activity}

Antioxidant scavenging activity was determined using the 1,1diphenyl-2-picrylhydrazyl free radical $\left(\mathrm{DPPH}^{\bullet}\right)$ as described by Blois [21] with some modifications; various dilutions of the test materials (ascorbic acid or extracts, $1.5 \mathrm{~mL}$ ) were mixed with a $0.2 \mathrm{mM}$ methanolic $\mathrm{DPPH}^{\bullet}$ solution $(1.5 \mathrm{~mL})$. After $30 \mathrm{~min}$ incubation period at $25^{\circ} \mathrm{C}$, the absorbance at $520 \mathrm{~nm}$ was recorded as $A_{\text {(sample) }}$. A control experiment was also carried out by applying the same procedure to a solution without the test material and the absorbance was recorded $\left(A_{(\text {blank })}\right)$. The free radical scavenging activity of each solution was then calculated as percentage inhibition according to the following equation: \% inhibition $=100 \times\left[\left(A_{(\text {blank })}-A_{(\text {sample })}\right) / A_{\text {(blank) }}\right]$

Extract antioxidant activity was expressed as $\mathrm{IC}_{50}$, defined as the concentration of the test material required to cause a 50\% decrease in initial $\mathrm{DPPH}^{\bullet}$ concentration. Values were estimated using linear regression. Ascorbic acid was used as a reference.

\subsection{ABTS $^{\bullet+}$ radical scavenging}

The radical scavenging capacity of the samples for the ABTS $^{\bullet+}$ (2,2'-azinobis-3-ethylbenzo-thiazoline-6-sulfonate) was determined as described by Re et al. [22]. ABTS $^{\bullet+}$ was generated by mixing a $7 \mathrm{mM}$ solution of ABTS ${ }^{\bullet+}$ at $\mathrm{pH} 7.4\left(5 \mathrm{mM} \mathrm{NaH}_{2} \mathrm{PO}_{4}, 5 \mathrm{mM}\right.$ $\mathrm{Na}_{2} \mathrm{HPO}_{4}$ and $154 \mathrm{mM} \mathrm{NaCl}$ ) with $2.5 \mathrm{mM}$ of potassium persulfate 
(final concentration) and stored in the dark at room temperature for $16 \mathrm{~h}$ before use. The mixture was diluted with water to give an absorbance of $0.70 \pm 0.02$ units at $734 \mathrm{~nm}$ using spectrophotometry. For each sample, a diluted methanol solution of the sample $(100 \mu \mathrm{L})$ was allowed to react with fresh $\mathrm{ABTS}^{\bullet+}$ solution $(900 \mu \mathrm{L})$, and the absorbance was measured 6 min after initial mixing. Ascorbic acid was used as a reference and the free radical scavenging capacity was expressed by $\mathrm{IC}_{50}(\mathrm{mg} / \mathrm{L})$ values, which represents the concentration required to scavenge $50 \%$ of $\mathrm{ABTS}^{\bullet+}$. The free radical scavenging capacity $\mathrm{IC}_{50}$ was determined using the same equation as used previously for the DPPH ${ }^{\bullet}$ method.

\subsection{Statistical analysis}

Results of antioxidant activity and total phenolic content were expressed as means \pm standard deviations of triplicate measurements. The confidence limits were set at $P<0.05$. Data analysis procedure (ANOVA) was performed in order to assess the data.

\section{Results and discussion}

\subsection{Influence of parameters for SFE}

\subsubsection{Influence of extraction duration}

An example of kinetics of the extraction process at 90 bar and $40^{\circ} \mathrm{C}$ is presented in Fig. 1(a). The global extraction yield increases linearly until about 30 minutes and then a plateau is reached. The initial linear shape of the curve suggests that extraction is limited by the solubility of volatile oil in $\mathrm{CO}_{2}$ or by solid-fluid equilibrium; internal diffusion limitation seems not to be present in these operating conditions.

We used a dynamic extraction method where the extraction duration is actually constituted of a period of static pretreatment (i.e., no $\mathrm{CO}_{2}$ flow rate) followed by a dynamic period (i.e., with constant $\mathrm{CO}_{2}$ flow rate). The static pretreatment allows equilibration of the solid and the fluid and does not require $\mathrm{CO}_{2}$ flow, and also allows $\mathrm{SCCO}_{2}$ dissolving into the oil present in secretory structures of the plant tissue (cells, cavities or ducts), previously opened by grinding, as described by Stamenić et al. [23].

In the first part of this study, the effect of static pretreatment on SFE efficiency was studied. Three static pretreatment durations (5, 10 and $15 \mathrm{~min}$ ), followed by $30 \mathrm{~min}$ dynamic extraction, were employed. The pressure and temperature were fixed at 90 bar and $40^{\circ} \mathrm{C}$ with particle diameter $1.5 \mathrm{~mm}$. Experimental global yields are presented on Fig. 1(b). It is seen that increasing the static extraction period, from 5 to $10 \mathrm{~min}$, increased extraction efficiency of volatile oil by more than $40 \%$. However, increasing the static extraction duration from 10 to 15 min had minimal effect on the extraction efficiency. Therefore, in all experiments, $10 \mathrm{~min}$ of static pretreatment was used.

Effect of dynamic extraction duration on extractability of the natural substances was investigated while keeping other parameters fixed. The dynamic method using three durations $(20,30$, and $60 \mathrm{~min}$ ) was tested with $10 \mathrm{~min}$ static pretreatment duration. The pressure, temperature and $\mathrm{CO}_{2}$ flow rate were $90 \mathrm{bar}, 40^{\circ} \mathrm{C}$ and $20 \mathrm{~g} / \mathrm{min}$ for all experiments.

Fig. 1(c) shows how extended dynamic extraction durations increase the efficiency of the process. However, the dependence between recovery and extraction duration gradually becomes flat. Therefore a dynamic method with 30 min was chosen in subsequent extractions.

\subsubsection{Influence of temperature}

The influence of temperature on the extraction yield of $T$. articulata at three temperature levels, 40,50 and $60^{\circ} \mathrm{C}$ is shown in Fig. 2. A high temperature is likely to improve mass transfer rates

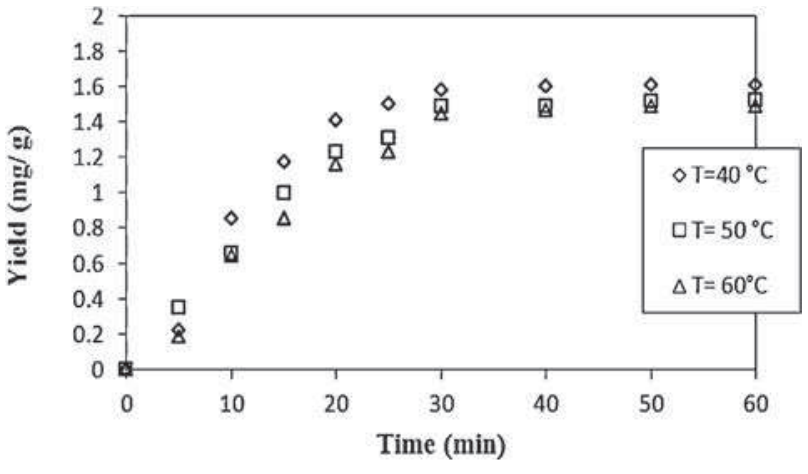

Fig. 2. Influence of the temperature on the T. articulata volatile oil yield for $1.5 \mathrm{~mm}$ particles as a function of the extraction time at $P=90$ bar and $W_{\mathrm{CO}_{2}}=20 \mathrm{~g} / \mathrm{min}$.

and thus kinetics of extraction. Nevertheless at low pressure, the density of $\mathrm{CO}_{2}$ is very sensitive to temperature and decreases with increasing temperature, leading possibly to reduced solvent power of $\mathrm{SCCO}_{2}$ depending on the competition between density of $\mathrm{SCCO}_{2}$ and volatility of the solute (retrograde solubility effect) [24]. This might be the reason of the observed decrease of the yield $\left(1.6-1.48 \mathrm{mg} / \mathrm{g}\right.$ ) when temperature is increased from 40 to $60^{\circ} \mathrm{C}$, as seen on Fig. 2. Such a similar result was also obtained by da Cruz Francisco et al. [25] in the case of the extraction of monoterpenes of eucalyptus oil. In addition, it is very likely that high-temperature extraction have a detrimental effect on the quality of the extract because of possible thermal degradation reactions. The possibility to perform efficient extraction of volatile compounds at low temperature is indeed one of the main advantages of the SFE technology when compared to traditional HD.

\subsubsection{Influence of pressure}

Fig. 3 presents the influence of pressure on the extraction yield of $T$. articulata leaves in $\mathrm{SC}-\mathrm{CO}_{2}$ at three pressure levels of 90 , 280 and 1000 bar for $30 \mathrm{~min}$ extraction duration (1.6, 19.2 and $25.5 \mathrm{~g} / \mathrm{kg}$, respectively).

The SFE yield of $T$. articulata was significantly influenced by the pressure, as can be seen in Fig. 3. In fact, increasing the extraction pressure from 90 to 280 bar increased the yield more than 9 times and, from 90 to 1000 bar, for more than 16 times. The high $\mathrm{CO}_{2}$ density at high pressure increased its solvent power and therefore, more substances were extracted. Also, it can be noticed that, especially, the increase from 90 to 280 bar is very efficient upon the yield.

High extraction pressure is likely to favor the extraction of heavy and more polar compounds such as phenolics, lipids or waxes. Therefore, in the present study, the phenolic content is expected to increase with increasing pressure ( 280 and 1000 bar).

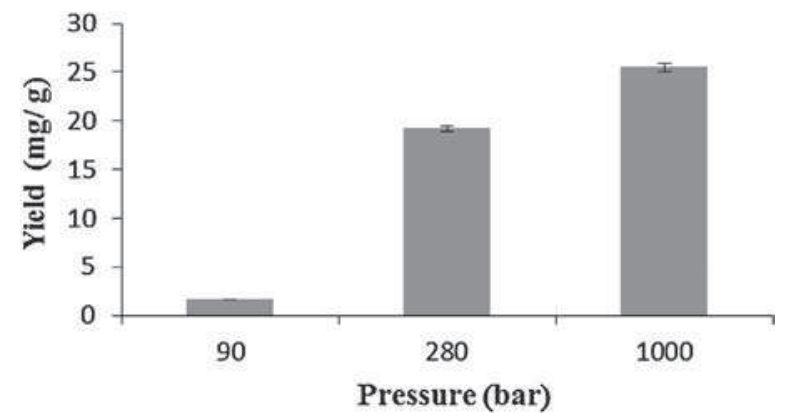

Fig. 3. Influence of the pressure on the $T$. articulata extraction yield for $1.5 \mathrm{~mm}$ particles, a $\mathrm{CO}_{2}$ flow rate of $20 \mathrm{~g} / \mathrm{min}, T=40^{\circ} \mathrm{C}$ and extraction duration $30 \mathrm{~min}$. 

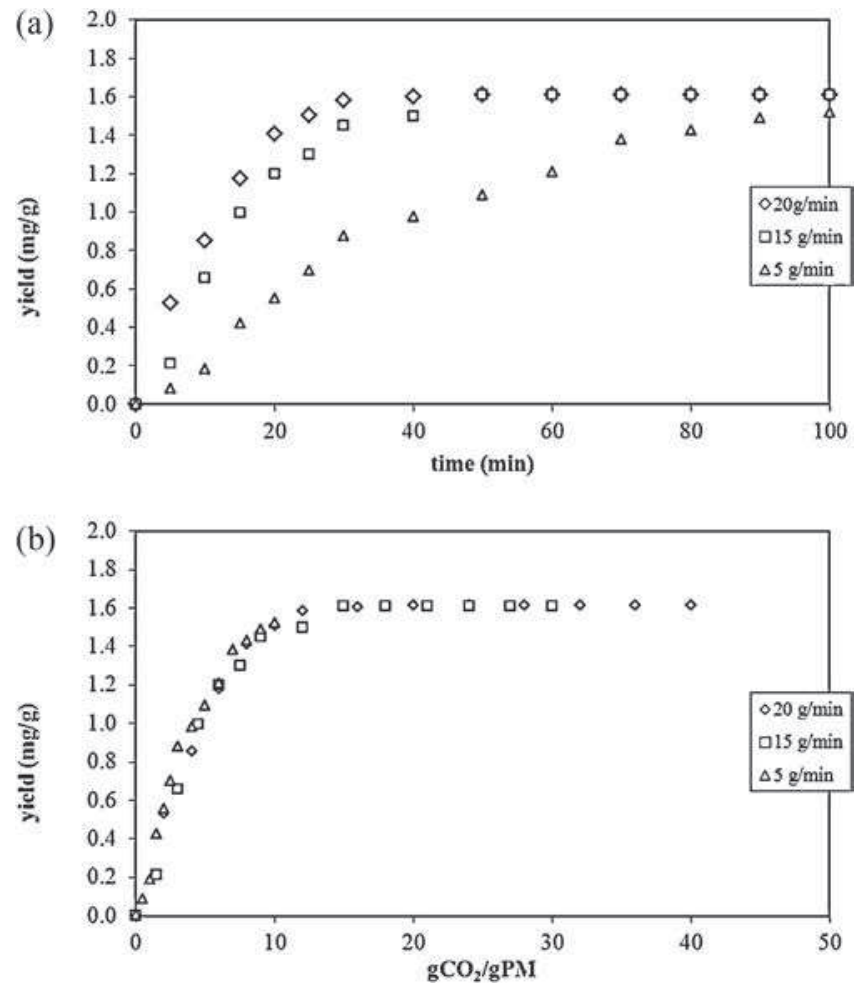

Fig. 4. T. articulata volatile oil yield for $1.5 \mathrm{~mm}$ particles at different $\mathrm{CO}_{2}$ flow rates as a function of the extraction time (a) and a function of amount of $\mathrm{CO}_{2}$ referred to initial amount of plant material (PM) (b) at $T=40^{\circ} \mathrm{C}$ and $P=90$ bar.

Nevertheless, increasing the pressure obviously results in a decrease of the selectivity of the extraction $[26,27]$.

\subsubsection{Influence of $\mathrm{CO}_{2}$ flow rate}

As shown in Fig. 4(a), for extraction at 90 bar and $40^{\circ} \mathrm{C}$, the $\mathrm{CO}_{2}$ flow rate exhibited a positive and significant effect on the $T$. articulata volatile oil extraction. This result indicates that, for $\mathrm{CO}_{2}$ flow rate equal to $5 \mathrm{~g} / \mathrm{min}, 60 \mathrm{~min}$ of extraction are not sufficient to achieve complete extraction while $30 \mathrm{~min}$ are sufficient at $20 \mathrm{~g} / \mathrm{min}$. Also, at all flow rates, the initial quasi-linear shape of the

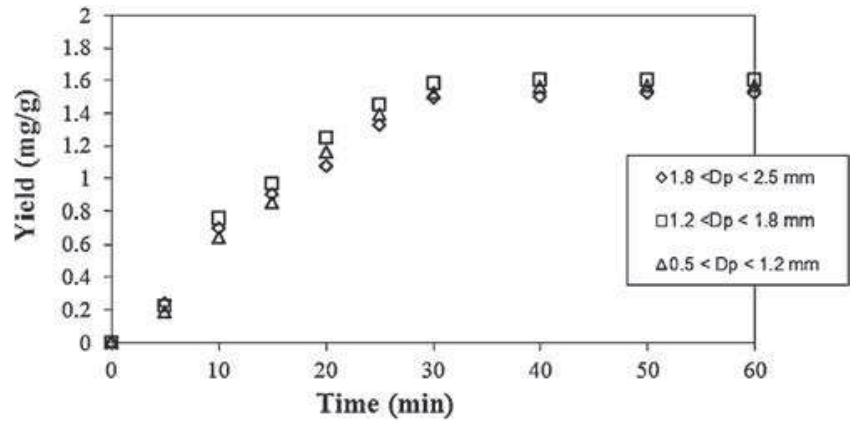

Fig. 5. T. articulata volatile oil yield for different mean particle sizes at a $\mathrm{CO}_{2}$ flow rate of $20 \mathrm{~g} / \mathrm{min}$, temperature $40^{\circ} \mathrm{C}$ and pressure $90 \mathrm{bar}$.

curves suggests the hypothesis that this SFE process is solubility or solid-fluid equilibrium limited.

When plotting the yield versus the amount of $\mathrm{CO}_{2}$ (Fig. 4(b)), the curves merge and this confirms the occurrence of solubility or equilibrium limitation for the extraction process. The slope of these curves gave the solute concentration in the output fluid $\left(C_{0}\right)$ at a value of $0.20 \times 10^{-2} \mathrm{~g} / \mathrm{gCO}_{2}$, a value which is below the value of solubility of usual terpenes $\left(\alpha\right.$-pinene for instance is $1.051 \times 10^{-2} \mathrm{~g} / \mathrm{g}$ $\mathrm{CO}_{2}$ at $T=40^{\circ} \mathrm{C}$ and $P=90$ bar [28]). When high mass transfer limitation is not suspected, this indicates very probable adsorption phenomena which limit the extraction process.

\subsubsection{Influence of particle size}

The effect of particle size on extraction rate is shown in Fig. 5. Despite some dispersion in the experimental points, the curves are similar, and especially the same final yield is reached after the same extraction duration (around $30 \mathrm{~min}$ ) for all particle sizes, indicating similar kinetic behavior. This result is in accordance with the suspected predominant equilibrium limitation which predicts kinetics almost independent of internal and external mass transfer, and therefore of particle size. The low impact of particle size on extraction kinetics is typical of glandular structures corresponding to secretory ducts $[23,29]$, as it is the case for plants of the Asteraceae, Apiaceae, Hypericaceae, Pinaceae or Coniferae family. These ducts are opened by grinding and the oil is easily accessible for $\mathrm{CO}_{2}$. $\mathrm{CO}_{2}$ dissolves in the early stage of extraction, leading to an increase of the volume of the oil that wets the surface of the plant. This
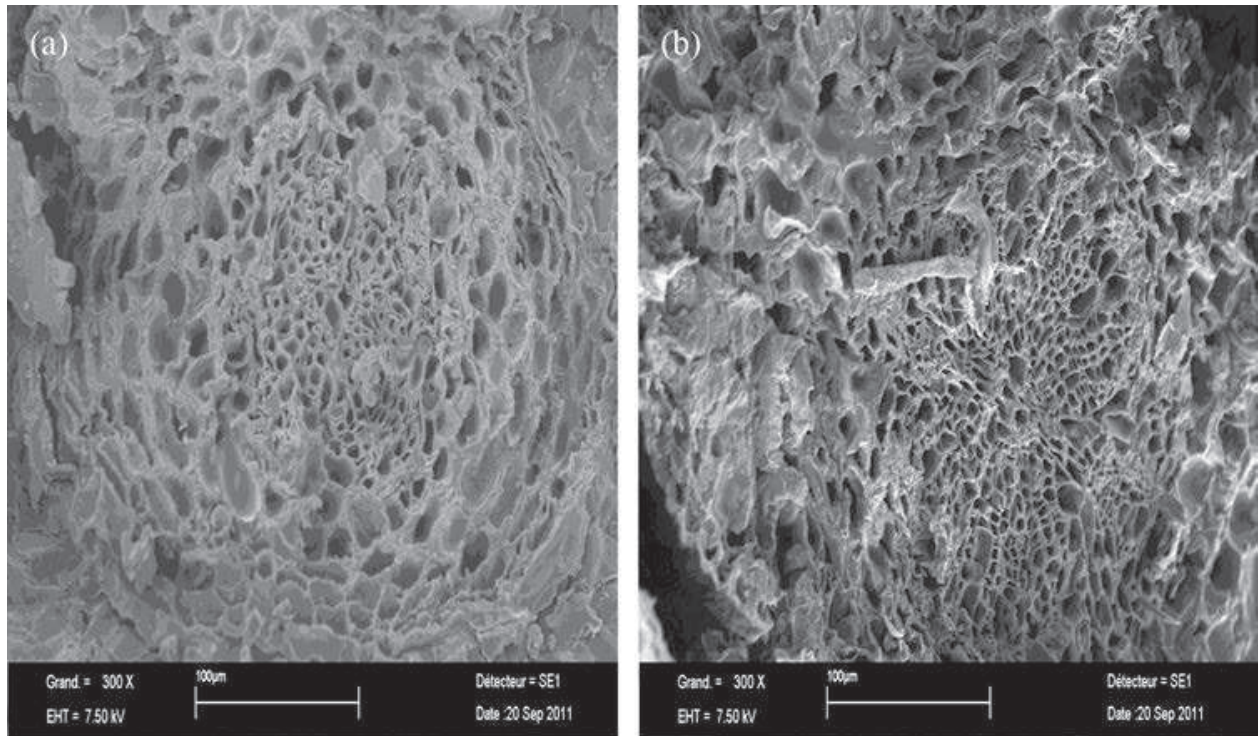

Fig. 6. SEM images of a section of $T$. articulata ground leaves before SFE (a) and leaves after SFE at 1000 bar, $40^{\circ} \mathrm{C}$ (b). 
Table 1

Chemical composition (GC-MS) and global yield of $T$. articulata extracts obtained by SFE at different pressures and by HD.

\begin{tabular}{|c|c|c|c|c|c|}
\hline & & \multicolumn{4}{|c|}{ Type of extraction technique } \\
\hline & & SFE & & & HD \\
\hline & Pressure (bar) & 90 & 280 & 1000 & - \\
\hline & Temperature $\left({ }^{\circ} \mathrm{C}\right)$ & 40 & 40 & 40 & 100 \\
\hline & Flow rate $(\mathrm{g} / \mathrm{min})$ & 20 & 20 & 20 & $0.02 \mathrm{~mL} / \mathrm{s}$ \\
\hline & Solvent & $\mathrm{CO}_{2}$ & $\mathrm{CO}_{2}$ & $\mathrm{CO}_{2}$ & Water \\
\hline & Extraction time (min) & 30 & 30 & 30 & 180 \\
\hline & Global yield (g/kg) & 1.6 & 19.2 & 25.5 & 0.61 \\
\hline RI & Compounds & $\%$ & $\%$ & $\%$ & $\%$ \\
\hline 906 & Santolina triene & 0.85 & & & 0.39 \\
\hline 931 & Artemesia triene & 0.8 & & & 0.6 \\
\hline 936 & $\alpha$-Pinene & 31.32 & & & 24.9 \\
\hline 940 & Cumene & 0.33 & & & \\
\hline 953 & $\alpha$-Fenchene & 0.22 & & & 0.14 \\
\hline 958 & Camphene & 0.49 & & & 0.45 \\
\hline 967 & $\beta$-Thujene & 2.64 & & & 1.99 \\
\hline 973 & 1-Ethyl-4-methylbenzene & 0.43 & & & \\
\hline 990 & Myrcene & 0.17 & & & 0.48 \\
\hline 1004 & Pseudolimonene & 0.26 & & & 0.37 \\
\hline 1008 & 3-Carene & 3.39 & & & 3.44 \\
\hline 1012 & $\alpha$-Terpinene & & & & 0.12 \\
\hline 990 & Myrcene & 0.17 & & & 0.48 \\
\hline 1037 & Limonene & 0.16 & & & 0.18 \\
\hline 1047 & 3-Methyl-1-decene & 0.13 & & & \\
\hline 1068 & Isoterpinolene & 0.26 & & & 0.46 \\
\hline 1077 & Ethyl maltol & & & & 0.26 \\
\hline 1079 & Artemisia alcohol & 0.19 & & & \\
\hline 1089 & $\alpha$-Terpinolene & & & & \\
\hline 1108 & cis-Thujone & 0.22 & & & 0.35 \\
\hline 1122 & trans-2,8-Menthadienol & 0.17 & & & 0.38 \\
\hline 1128 & $\alpha$-Campholenal & 3.44 & 0.1 & 0.43 & 3.84 \\
\hline 1132 & Isothujol & & & & 0.17 \\
\hline 1148 & Camphene hydrate & 1.25 & & & 4.36 \\
\hline 1157 & Isoborneol & & & & \\
\hline 1159 & $\beta$-Terpineol & 0.18 & & & 0.73 \\
\hline 1172 & 3,5,5-Trimethyl-1,4-cyclohexanedione & 0.09 & 0.14 & 1.41 & \\
\hline 1193 & Myrtenal & 0.23 & & & 0.08 \\
\hline 1200 & Z-Dihydrocarvone & 0.18 & & & 0.34 \\
\hline 1232 & cis-Carveol & 0.15 & & & \\
\hline 1266 & Linalool acetate & 18.18 & 1.72 & & 21.44 \\
\hline 1279 & p-sec-Butylphenol & & & & 0.58 \\
\hline 1318 & (Z)-3-Hexenyl 2-methyl-(E)-2-butenoate & 0.38 & & & \\
\hline 1327 & Trans-Pulegone oxide [a] & 0.91 & 0.31 & & 1.53 \\
\hline 1356 & $\alpha$-Cubebene & 1.11 & 0.47 & & 0.26 \\
\hline 1370 & Cyclosativene & 0.72 & & & 0.16 \\
\hline 1383 & $\beta$-Bourbonene & 1.74 & & & 0.44 \\
\hline 1400 & $\gamma$-Caryophyllene & 4.16 & 2.05 & & 2.53 \\
\hline 1409 & Aromadendrene & & & & \\
\hline 1435 & $\alpha$-trans-Bergamotene & 1.29 & 0.59 & & 1.04 \\
\hline 1444 & $\alpha$-Caryophyllene & & & & 0.13 \\
\hline 1455 & $\alpha$-Patchoulene & 0.48 & & & 0.18 \\
\hline 1461 & Alloaromadendrene & 7.55 & 1.41 & & 1.14 \\
\hline 1474 & $\gamma$-Muurolene & & & & 0.35 \\
\hline 1479 & $\gamma$-Curcumene & 0.58 & & & 0.43 \\
\hline 1494 & $\alpha$-Zingiberene & 2.14 & 2.38 & & 0.53 \\
\hline 1501 & $\alpha$-Amorphene & 1.39 & & & 1.64 \\
\hline 1516 & $\alpha$-Selinene & 0.32 & & & \\
\hline 1534 & incisol & 0.17 & & & 0.59 \\
\hline 1557 & Caryophyllene alcohol & 1.06 & & & \\
\hline 1568 & Caryophyllene oxide & 1.82 & 2.45 & & 4.24 \\
\hline 1588 & $\beta$-Oplopenone & & & & 0.38 \\
\hline 1594 & Cedrenol & 0.48 & 1.03 & & 2 \\
\hline 1613 & 1-epi-Cubenol & 0.52 & 2.12 & & 2.83 \\
\hline 1619 & trans-Isolongifolanone & & & & 0.42 \\
\hline 1626 & $\gamma$-Eudesmol & 0.58 & & & 2.56 \\
\hline 1642 & Spathulenol & 0.43 & 0.77 & & 2.37 \\
\hline 1660 & 14-Hydroxy-9-epi-(E)-caryophyllene & 0.14 & 0.5 & & 0.97 \\
\hline 1673 & Cedr-8-en-13-ol & & & & 0.23 \\
\hline 1678 & cis-Alpha-santalol & 0.44 & 1.24 & & 1.74 \\
\hline 1717 & (Z)-2-Heptadecene ${ }^{\mathrm{a}}$ & 0.22 & & & \\
\hline 1761 & 1,10-Dihydronootkatone & & 0.88 & & 0.08 \\
\hline 1928 & 16-Hexadecanolide & & 0.43 & & 0.15 \\
\hline 1962 & Palmitic acid & & 2.98 & 36.19 & \\
\hline 1991 & Manoyl oxide & 0.13 & & & 0.26 \\
\hline 2008 & Kaur-16-ene & 0.14 & & & 0.1 \\
\hline
\end{tabular}




\begin{tabular}{|c|c|c|c|c|c|}
\hline & & \multicolumn{4}{|c|}{ Type of extraction technique } \\
\hline & & \multicolumn{3}{|l|}{ SFE } & \multirow{2}{*}{$\begin{array}{l}\text { HD } \\
0.32\end{array}$} \\
\hline 2053 & abietatriene & & & & \\
\hline 2095 & Heneicosane & 0.4 & 3.66 & & 0.09 \\
\hline 2135 & 1R-pimaral & 0.13 & 6.09 & & 0.27 \\
\hline 2143 & Cubitene & 0.22 & & & \\
\hline 2187 & Cembrene A ketone & 0.25 & 1.37 & & 0.14 \\
\hline 2216 & 15-Ripperten-3alpha-ol & 0.41 & 2.11 & & 0.52 \\
\hline 2223 & trans-Totarol & 0.12 & & & \\
\hline 2274 & Larixol $^{\mathrm{a}}$ & & 2.17 & & \\
\hline 2288 & 2-Methyltricosane & & 10.29 & & \\
\hline 2311 & trans-Totarol & & 4.85 & 0.05 & 0.07 \\
\hline 2368 & androst-5-en-17-ol, 4,4 dimethyl & & 2.28 & 2.49 & \\
\hline 2383 & Podocarp-7-en-3-one, 13a-methyl-13-vinyl & & 7.77 & 25.53 & \\
\hline 2473 & Docosyl acetate & & 14.4 & 1.35 & \\
\hline 2922 & Abietic acid & & & 0.31 & \\
\hline 2925 & ni & & & 1.05 & \\
\hline \multirow[t]{12}{*}{2930} & Podocarp-8(14)-en-15al, 13a-methyl-13-vinyl & & & 10.79 & \\
\hline & ni $(M=410)$ & & & 0.73 & \\
\hline & $\mathrm{ni}(M=552)$ & & & 2.14 & \\
\hline & $\mathrm{ni}(M=618)$ & & & 8.96 & \\
\hline & $\operatorname{ni}(M=296)$ & & 7.34 & 7.98 & \\
\hline & Number of compounds & 56 & 29 & 14 & 56 \\
\hline & Monoterpene hydrocarbons & 40.73 & 0 & 0 & 34 \\
\hline & Monoterpene oxygenated & 6.92 & 0.41 & 0.43 & 12.36 \\
\hline & Sesquiterpenes hydrocarbons & 21.48 & 6.9 & 0 & 8.83 \\
\hline & Sesquiterpenes oxygenated & 5.64 & 8.99 & 0 & 18.41 \\
\hline & Others & 21.14 & 67.55 & 97.71 & 25.03 \\
\hline & Total & 96.24 & 83.85 & 98.14 & 98.63 \\
\hline
\end{tabular}

ni, not identified.

a Tentative identification supported by good match of mass spectrum.

hypothesis could explain the predominance of equilibrium phenomena as compared to internal mass transfer in the extraction process.

\subsubsection{Effect of $\mathrm{SCCO}_{2}$ extraction on the structure of vegetal material}

Optical microscope or Scanning Electron Microscope (SEM) analyses of the material were done to visualize its structure and the effect of the extraction process upon this structure. The initial structure of the ground leaves from $T$. articulata, observed by SEM, is shown in Fig. 6(a). From comparison with Fig. 6(b), it is seen that SFE had almost no effect on the structure of the plant, at least on a visual point of view. Moreover, SEM images tend to confirm the hypothesis of secretory ducts, since the plant is actually made of a core of interconnected channels surrounded by a dense bark.

\subsection{Characterization of extracts and comparison with $H D$}

\subsubsection{Chemical composition of the extracts}

The global yield and the results of the GC-MS analysis of volatile oil obtained from $T$. articulata by SFE and HD are presented in Table 1.

As expected, there was a significant difference in the extraction yields between the extracts obtained using HD and SFE at the three pressures. Extraction at high pressure was found to be more efficient than other conditions studied in extracting the antioxidant components present in the $T$. articulata leaves.

Although a total of 86 compounds were identified, for the sake of simplicity, the discussion has been restricted to the major components identified for each method. These major components are presented in Table 2, where a total of 28 components with a percentage higher than $2 \%$ are gathered. Results are presented in terms of relative proportion (\% of area of the peak in the chromatograms) and amount in $\mathrm{mg} / \mathrm{kg}$ of extract. Compounds appear in Table 2 in the order of decreasing volatility. Although this could lead to approximate results, because terpenes are the main components, it has been considered here that palmitic acid, abietic acid and terpenes have similar response factor.

When comparing composition of essential oil (HD) and volatile oil obtained by SFE at 90 bar, no great differences were observed and $\alpha$-pinene and linalool acetate are predominant in the extracts obtained with these methods. However, the compounds in extracts obtained by SFE at 280 and 1000 bar are significantly different compared to those obtained by HD or SFE at 90 bar.

It appears that the higher the pressure of SFE, the lower the number of detected compounds, which in that case corresponds to heavy compounds. For example, only 14 volatile compounds have been detected by GC-MS in the extract obtained by SFE at 1000 bar (only 10 have been reported in Table 2). Note also that, due to the gas chromatography method, only high molecular mass compounds with retention index (RI) value greater than 1900 were detected. On the other side, the essential oil (HD), volatile oil of SFE (at 90 bar) and extract from SFE at 280 bar were composed of 56, 56 and 29 compounds, respectively. This result is surprising because high pressure operation allows extracting more compounds due to the increased solvent power of $\mathrm{SCCO}_{2}$. Indeed, this results from an "artifact" of the recovery system of the A21 (SFE1000 bar) apparatus which was not very effective or at least incorrectly used. This apparatus has only one separator (conversely to SF200 extraction which has 3 separators in series). Experiments at 280 and 1000 bar (where volatile components were not detected) were done on A21 apparatus while experiments at 90 bar were done on the SF200 extraction (where these volatile components were recovered and detected). So it is very probable that the unique separator of A21 has favored the selective loss of the volatile components that obviously were extracted at high pressure but not recovered in the low pressure recovery zone. This explains that low molecular mass compounds do not appear in the composition.

In volatile oils obtained by HD and SFE at 90 bar, the main constituents were $\alpha$-pinene (24.90-31.32\%), linalool acetate (21.44-18.18\%), alloaromadendrene (1.14-7.55\%), camphene hydrate (4.36-1.25\%) and $\gamma$-caryophyllene (2.53-4.16\%). The main 
Table 2

Chemical composition obtained by GC-MS (abundance $>2 \%$ ) and global yield of $T$. articulata extracts obtained by SFE at different pressures and by HD.

\begin{tabular}{|c|c|c|c|c|c|c|c|c|c|}
\hline & & \multicolumn{8}{|c|}{ Type of extraction technique } \\
\hline & & \multicolumn{7}{|l|}{ SFE } & \multirow[t]{2}{*}{ HD } \\
\hline & Flow rate $(\mathrm{g} / \mathrm{min})$ & 20 & & 20 & & 20 & & $0.02 \mathrm{~mL} / \mathrm{s}$ & \\
\hline & Temperature $\left({ }^{\circ} \mathrm{C}\right)$ & 40 & & 40 & & 40 & & 100 & \\
\hline & Pressure & 90 & & 280 & & 1000 & & - & \\
\hline & Solvent & $\mathrm{CO}_{2}$ & & $\mathrm{CO}_{2}$ & & $\mathrm{CO}_{2}$ & & Water & \\
\hline & Extraction time (min) & 30 & & 30 & & 30 & & 180 & \\
\hline & Global yield (mg/kg) & 1.63 & & 19.2 & & 25.9 & & 0.61 & \\
\hline RI & Compounds & $\%$ & $\mathrm{mg} / \mathrm{kg}$ & $\%$ & $\mathrm{mg} / \mathrm{kg}$ & $\%$ & $\mathrm{mg} / \mathrm{kg}$ & $\%$ & $\mathrm{mg} / \mathrm{kg}$ \\
\hline 936 & $\alpha$-Pinene & 31.32 & 511 & & & & & 24.9 & 152 \\
\hline 967 & $\beta$-Thujene & 2.64 & 43 & & & & & 1.99 & 12 \\
\hline 1004 & Pseudolimonene & 0.26 & 4 & & & & & 0.37 & 2 \\
\hline 1008 & 3-Carene & 3.39 & 55 & & & & & 3.44 & 21 \\
\hline 1128 & $\alpha$-Campholenal & 3.44 & 56 & 0.1 & 19 & 0.43 & 111 & 3.84 & 23 \\
\hline 1148 & Camphene hydrate & 1.25 & 20 & & & & & 4.36 & 27 \\
\hline 1266 & Linalool acetate & 18.18 & 296 & 1.72 & 330 & & & 21.44 & 131 \\
\hline 1400 & $\gamma$-Caryophyllene & 4.16 & 68 & 2.05 & 394 & & & 2.53 & 15 \\
\hline 1461 & Alloaromadendrene & 7.55 & 123 & 1.41 & 271 & & & 1.14 & 7 \\
\hline 1494 & $\alpha$-Zingiberene & 2.14 & 35 & 2.38 & 457 & & & 0.53 & 3 \\
\hline 1568 & Caryophyllene oxide & 1.82 & 30 & 2.45 & 470 & & & 4.24 & 26 \\
\hline 1613 & 1-epi-Cubenol & 0.52 & 8 & 2.12 & 407 & & & 2.83 & 17 \\
\hline 1626 & $\gamma$-Eudesmol & 0.58 & 9 & & & & & 2.56 & 16 \\
\hline 1642 & Spathulenol & 0.43 & 7 & 0.77 & 148 & & & 2.37 & 14 \\
\hline 1962 & Palmitic acid & & & 2.98 & 572 & 36.19 & 9373 & & \\
\hline 2095 & Heneicosane & 0.4 & 7 & 3.66 & 703 & & & 0.09 & 1 \\
\hline 2135 & 1R-pimaral & 0.13 & 2 & 6.09 & 1169 & & & 0.27 & 2 \\
\hline 2216 & 15-Ripperten-3alpha-ol & 0.41 & 7 & 2.11 & 405 & & & 0.52 & 3 \\
\hline 2274 & Larixol $^{\mathrm{a}}$ & & & 2.17 & 417 & & & & \\
\hline 2288 & 2-Methyltricosane & & & 10.29 & 1976 & & & & \\
\hline 2311 & trans-Totarol & & & 4.85 & 931 & 0.05 & 13 & 0.07 & \\
\hline 2368 & Androst-5-en-17-ol, 4,4 dimethyl & & & 2.28 & 438 & 2.49 & 645 & & \\
\hline 2383 & Podocarp-7-en-3-one, 13a-methyl-13-vinyl & & & 7.77 & 1492 & 25.53 & 6612 & & \\
\hline 2473 & Docosyl acetate & & & 14.4 & 2765 & 1.35 & 350 & & \\
\hline \multirow[t]{5}{*}{2930} & Podocarp-8(14)-en-15al, 13a-methyl-13-vinyl & & & & & 10.79 & 2795 & & \\
\hline & $\mathrm{ni}(M=552)$ & & & & & 2.14 & 554 & & \\
\hline & ni $(M=618)$ & & & & & 8.96 & 2321 & & \\
\hline & $\operatorname{ni}(M=296)$ & & & 7.34 & 1409 & 7.98 & 2067 & & \\
\hline & Total & 78.62 & 1282 & 76.94 & 14,772 & 95.91 & 24,841 & 77.49 & 473 \\
\hline
\end{tabular}

ni, not identified.

a Tentative identification supported by good match of mass spectrum.

compounds of extracts obtained by SFE at 280 and 1000 bar were palmitic acid (2.98-36.19\%), docosyl acetate (14.40-1.35\%), podocarp-7-en-3-one, 13a-methyl-13-vinyl (7.77-25.53\%), 2-methyltricosane (10.29-0\%), podocarp-8(14)-en-15al, 13amethyl-13-vinyl (0-10.79\%) and 1R-pimaral (6.09-0\%). Also, some compounds with high molecular mass were detected but not identified. For instance, the amount of some of these unidentified compounds was significant in SFE extract at 1000 bar $(8.96 \%$ $(M=618 \mathrm{~g} / \mathrm{mol})$ and $7.98 \%(M=296 \mathrm{~g} / \mathrm{mol}))$.

On the other hand, important difference between the compounds of each extracts can be seen in term of quantity $(\mathrm{mg} / \mathrm{kg})$. It is the case for example of $\alpha$-pinene which was identified as the major compound in HD and SFE at 90 bar, where quantities determined in HD and SFE extracts, were $152 \mathrm{mg} / \mathrm{kg}$ (for $24.9 \%$ of global oil) and $511 \mathrm{mg} / \mathrm{kg}$ (for $31.31 \%$ of global oil) respectively.

It is interesting to compare these results with the few studies that have been conducted on the essential oils of $T$. articulata. Ben Hadj Ahmed et al. [30] have studied essential oil from T. articulata plants harvested in the region of Sned Gafsa (Tunisia) and have only reported about antioxidant activity of the essential oil and not about its chemical composition. Tekaya-Karoui et al. [31] have worked on T. articulata plants harvested in the region of Zaghouas (Tunisia) and have shown that chemical composition was different, depending on the part of the plant. In the essential oil obtained from branches, the major compounds were camphene (43.2\%), Z-muurolène (29.0\%) and p-cymene-8-ol (10.4\%) while essential oil from the roots was richer in camphene (70.2\%). A study of Barrero et al. [32] upon the chemical composition of essential oil from leaves and wood of T. articulata plants harvested in the region of Amsa Téouan (Morocco) has shown that the leaves were rich in bornyl acetate (16.5\%), camphor (19.1\%) and borneol (9.6\%) and that the essential oil from the wood was rich in cedrol (28.2\%) and 1,7-di-epi-cedrol (17.9\%). The results reported by Aitigri [33] have shown that essential oil from wood of T. articulata plants harvested in the region of Rabat (Morocco) were rich in carvacrol and $\alpha$-cedrol. Another study of Zrira et al. [34] upon T. articulata plants from the region of Khemisset and Aoulouz (Morocco) has reported the predominant presence of carvacrol (21.3-36.4\%), $\alpha$-cedrene (10.1-13.1\%), cedrol (1-7.3\%) and terpinen-4-ol (2.8-6\%). In a study from Buhagiar et al. [35], 18 compounds were identified in aerial parts of $T$. articulata plants, where $\alpha$-pinene, limonene, camphor and bornyl acetate were the main compounds. From this survey, it is seen that the chemical compositions of $T$. articulata essential oils is very dependent on the harvesting place and on the specific part of the plant. To the best of our knowledge, no study upon chemical composition of SFE extracts of $T$. articulata has yet been proposed.

\subsubsection{Phenolics content and antioxidant activity of the extracts}

The concentration of phenolics in the extracts, expressed as Gallic Acid Equivalent (GAE) is shown in Table 3. As expected, the amount of phenolic compounds in the SFE extracts at high pressure was the highest $(102.03 \pm 4.57$ and $267.90 \pm 8.06 \mathrm{mg} \mathrm{GAE} / \mathrm{g}$ plant material for 280 bar and 1000 bar, respectively), followed by SFE at 90 bar $9.70 \pm 0.57$ and HD $8.89 \pm 0.16 \mathrm{mg} \mathrm{GAE} / \mathrm{g}$ dry plant material.

The results from Table 3 show that, although the quantity of phenolics is low and almost identical for the HD essential oil and 
Table 3

Total phenolics content and antioxidant activity of $T$. articulata extracts obtained by SFE at different pressures and by HD.

\begin{tabular}{|c|c|c|c|c|c|c|}
\hline \multirow[t]{2}{*}{ Samples } & \multicolumn{2}{|c|}{$\begin{array}{l}\text { Phenolics } \\
\text { (GAE mg/g) }\end{array}$} & \multicolumn{2}{|l|}{ DPPH } & \multicolumn{2}{|l|}{ ABTS } \\
\hline & GAE mg/g & \pm & $\mathrm{IC}_{50}$ & \pm & $\mathrm{IC}_{50}$ & \pm \\
\hline SFE 90 bar & 9.70 & 0.57 & 146.02 & 1.99 & 40.91 & 0.53 \\
\hline SFE 280 bar & 102.03 & 4.57 & 120.21 & 3.65 & 33.55 & 0.40 \\
\hline SFE 1000 bar & 267.90 & 8.06 & 108.16 & 3.07 & 29.77 & 1.30 \\
\hline HD & 8.89 & 0.16 & 3681.49 & 69.33 & 324.45 & 14.21 \\
\hline
\end{tabular}

GAE, Gallic Acid Equivalent.

SFE extract at 90 bar, their antioxidant activity is different. The SFE extract at $90 \mathrm{bar}\left(\mathrm{IC}_{50}(\mu \mathrm{g} / \mathrm{ml})=40.91 \pm 0.53\right)$ is about 8 times more active than essential oil $\left(\mathrm{IC}_{50}(\mu \mathrm{g} / \mathrm{ml})=324.45 \pm 14.21\right)$. These results suggest that the SFE volatile oil from $T$. articulata, is more concentrated with antioxidants and could be used as a potential source of natural antioxidants with possible applications in food systems. The presence of antioxidants in this plant is confirmed by a previous publication [11] where phenolics and antioxidant activity of Algerian T. articulata leaves extract were determined. These authors showed that extract of $T$. articulata from Algeria obtained by heat reflux with distilled water exhibited good antioxidant activity (IC50 $(\mu \mathrm{g} / \mathrm{ml})=9.519 \pm 0.521$ and high total phenolic content $\left(\mathrm{mg} \mathrm{GAE} \mathrm{g}^{-1}\right)=206.187 \pm 16.612$ ). Although GC-MS is able to identify some of these molecules, they were not detected in our case. Therefore the high measured antioxidant activity can be explained by the presence of high molecular weight phenolics (tannins, anthocyanins, etc.) which cannot be detected using GC-MS.

Another explanation could be the occurrence of low quantities of highly active phenolic compounds. For example Harish Nayaka et al. [36] reported that, from values of $\mathrm{IC}_{50}$ obtained for phenolic acid extracts of swallow roots, vanillic acid was 45 times less active than gallic acid.

\subsection{Mathematical modeling}

\subsubsection{Preliminary analysis of the physical phenomena}

Because vegetal matter is very diverse, numerous models describing supercritical extraction process are available in the literature, from the simple empirical ones to the most complex that are able to handle all physical phenomena occurring during extraction. The choice is always difficult and the most complex model might not be the most useful because it is associated with the estimation of numerous parameters, while some of them may have a negligible influence. Moreover their complexity prevents sometimes from easy understanding which is necessary to select the optimal conditions for the extraction process, especially when scale-up is envisaged. So, qualitative interpretation of kinetic curves together with the use of easy-to-implement simplified models is very useful. Especially, qualitative study of the extraction curves at different flow-rates and different particle sizes is very instructive. Such an approach has been recently recommended by Sovová [17] in a recent paper which provides a simplified method based on the use of characteristic times for all involved physical processes. Comparison of these characteristic times greatly helps for discriminating the prominent parameters. However, care must be taken to insure that, when scaling up, the choice of these parameters remains pertinent.

We have restricted our approach to volatile oil supercritical extraction and therefore the modeling is proposed for results obtained at 90 bar and $40^{\circ} \mathrm{C}$

In the case presented here, from the overlapping of curves of Fig. 4(b), as indicated in Section 3.1.4, a limitation by the adsorption phenomenon is strongly suspected. In this case, when external mass transfer is not involved, estimation of the adsorption coefficient is obtained from the initial slope of Fig. 4b. The hypothesis of negligible external mass transfer limitation can be assessed by computing external mass transfer characteristic time $t_{f}$ [17]. External mass transfer characteristic time $t_{f}$ depends on $k_{f}$ (external mass transfer coefficient), $\lambda$ which is the volume/surface ratio of the particle $(=R / 3$ for spherical particles) and $\varepsilon$, the void fraction of the particle bed.

$t_{f}=\frac{\varepsilon}{1-\varepsilon} \frac{\lambda}{k_{f}}$

$t_{1}=\frac{G}{K_{m} \cdot q^{\prime} \cdot\left(1-\exp \left(-1 / \theta_{f}\right)\right)}$

The extraction time $t_{1}$ corresponding to the end of the linear part of the extraction curve is thus a function of $q^{\prime}$ which is the $\mathrm{CO}_{2}$ flowrate referred to the mass of solid, $G$, the fraction of easily accessible cells, and $K_{m}$ which is the solute partition coefficient $(\mathrm{kg}$ plant $/ \mathrm{kg}$ solvent) defined as $C=K_{m} \cdot q$, where $C$ is the concentration of volatile oil in the fluid phase ( $\mathrm{g}$ solute $/ \mathrm{gCO}_{2}$ ) and $q$ is the concentration of volatile oil in the solid phase (g solute/g plant). $\Theta_{f}$, is the ratio of the external transfer characteristic time $t_{f}$ to the residence time $t_{r}$. This latter is given by:

$t_{r}=\frac{\gamma}{q^{\prime}}$

where $\gamma$ is the ratio between initial $\mathrm{CO}_{2}$ mass and solid mass in the extractor.

To provide a quantitative assessment of these characteristic times, extraction at the higher flow-rate, $20 \mathrm{~g} / \mathrm{min}$, for assumed spherical $1.5 \mathrm{~mm}$ diameter particles, is considered because this case is the most likely to exhibit influence of external mass transfer. Considering a void fraction $\varepsilon=0.457$, the characteristic time for external transfer $t_{f}$ is computed at $1.05 \mathrm{~s}$ using the correlation of Tan et al. [37] for the evaluation of $k_{f}$ (which yielded $k_{f}=1.61 \times 10^{-4} \mathrm{~m} \mathrm{~s}^{-1}$ ) and $t_{r}$ is equal to $75 \mathrm{~s}$. The value of $t_{f}$ being low as compared to $t_{r}$ confirms that external mass transfer resistance can be neglected. This result makes it possible to use a simple equilibrium model for the linear part of the extraction curve. Such an approach was proposed by Reis-Vasco et al. [38] for the extraction of pennyroyal essential oil. Visually, from Fig. 4 (a), the value $G=0.7$ for the accessible fraction is estimated, corresponding to the end of the linear part of the curves which occurs at $t_{1}=750 \mathrm{~s}$.

The interpretation of the curved final part of the extraction curves is trickier. In a first approach, as suggested by Sovová, this part would correspond to an internal mass transfer limited process, concerning the extraction of the nonaccessible part of the solute. If this was true, final parts of curves of Fig. 4(b) (which relates the extraction yield to the mass of $\mathrm{CO}_{2}$ used) should exhibit influence of the flow rate, while this is not the case because curves overlap up to the end of extraction. In addition, a confirmation of this hypothesis is found when attempting to fit the experimental data with the simplified model for plug-flow with adsorption given in Sovová's paper [17]:

$e=x_{u}-(1-G) x_{u} \exp \left(-\frac{t-t_{1}}{t_{c o m b, i}}\right) \quad$ for $t \geq t_{1}$

where $x_{u}$ is the initial solute content of the solid before extraction (it is determined from the value of the final yield of the extraction curves at a value $x_{u}=1.6 \times 10^{-2} \mathrm{~g} / \mathrm{g}$ ). The combined characteristic time of mass transfer $t_{c o m b, i}$ is obtained, as a function of $t_{f}, K_{m}$ and $t_{i}$ (internal mass transfer characteristic time) that involves the effective internal effective diffusion coefficient $D_{e}$. These characteristic times are given by:

$t_{i}=\frac{R^{2}}{15 D_{e}}$ 
$t_{c o m b, i}=t_{i}+\frac{t_{f}}{\gamma \cdot K_{m}}$

When using this approach for the final part of the experimental curves obtained at different $\mathrm{CO}_{2}$ flow-rates, parameter identification yielded different values of the internal diffusion coefficient $D_{e}$ for each flow-rate, while this parameter should not be affected by the flow-rate.

All these elements indicate that the final curvature of the extraction curves corresponds more probably to the influence of axial dispersion (which is not accounted for in the simplified model). Eventually, this suggests an adsorption limited extraction process where all the solute is accessible with negligible external mass transfer limitation, but where significant axial dispersion is present. The computation of the Peclet number, $\mathrm{Pe}=h \cdot u /\left(D_{L} \cdot \varepsilon\right)$, with the relation of Funakuzuri [39] for the axial dispersion coefficient, yielded $\mathrm{Pe}=19$ which is quite low and ascertains the hypothesis of a non-negligible axial dispersion influence (see details below in the paragraph about modeling). This makes it possible to use a simplified model which indeed corresponds to the first part of the Reis-Vasco's model, i.e., differential mass balance equations corresponding to the case of extraction limited by the solute adsorption and describing the flow pattern as a piston flow with axial dispersion [38].

\subsubsection{Description of the equations of the model}

Mass balance equations in that case correspond to the following assumptions: (1) the superficial velocity of $\mathrm{SCCO}_{2}, u$, is constant during the process, (2) the process is isothermal and pressure drop is neglected, (3) volatile oil is described by a single component, the "solute" and (4) a linear equilibrium relationship is assumed defined as $C=K_{m} \cdot q$. The corresponding model equations, boundary and initial conditions are (Reis-Vasco et al.) [38]:

$\rho_{f} \varepsilon \frac{\partial C}{\partial t}+\rho_{s}(1-\varepsilon) \frac{\partial q}{\partial t}=-\rho_{f} u \frac{\partial C}{\partial z}+D_{L} \rho_{f} \varepsilon \frac{\partial^{2} C}{\partial z^{2}}$

$C=K_{m} \cdot q$

$t=0, \quad C=C_{0} \quad$ and $\quad x_{u}=q_{0}+\gamma C_{0} \quad z>0$

$z=0, \quad \frac{u}{\varepsilon} C-D_{L} \frac{\partial C}{\partial z}=0 \quad t>0$

$Z=L, \quad \frac{\partial C}{\partial z}=0 \quad t>0$

Eq. (7) can be re-written as:

$\left(1+\frac{(1-\varepsilon)}{\varepsilon} \frac{\rho_{s}}{\rho_{f}} \frac{1}{K_{m}}\right) \frac{\partial C}{\partial t}+\frac{u}{\varepsilon} \frac{\partial C}{\partial z}-D_{L} \frac{\partial^{2} C}{\partial z^{2}}=0$

where $t$ is extraction time, $z$ is the axial coordinate of the extraction bed, $C_{0}$ is the concentration of volatile oil in the fluid phase at the beginning of the extraction process which corresponds to the equilibrium with the initial solid phase concentration $q_{0}, q_{0}$ and $C_{0}$ being related by Eq. (9), $\varepsilon$ is the bed void fraction, $\rho_{s}$ density of vegetable matter, and $D_{L}$ is the axial dispersion coefficient $\left(\mathrm{m}^{2} / \mathrm{s}\right)$.

The system of equations was solved with the Matlab ${ }^{\circledR}$ software. Initial concentration of solute in $\mathrm{CO}_{2}, \mathrm{C}_{0}$, was computed from the initial slope of Fig. 4(b) and, the value $C_{0}=0.2 \times 10^{-2} \mathrm{~g}$ solute $/ \mathrm{g} \mathrm{CO}_{2}$ was obtained. Equilibrium adsorption constant $K_{m}\left(=C_{0} / q_{0}\right)$ was then computed at $K_{m}=0.14 \mathrm{~kg}$ plant $/ \mathrm{kg} \mathrm{CO}$.

At 90 bar and $40^{\circ} \mathrm{C}$, density and viscosity of $\mathrm{CO}_{2}$ were evaluated at $\rho_{f}=448.45 \mathrm{~kg} / \mathrm{m}^{3}$ and $\mu_{f}=40.1 \times 10^{-6}$ Pa s. The axial dispersion

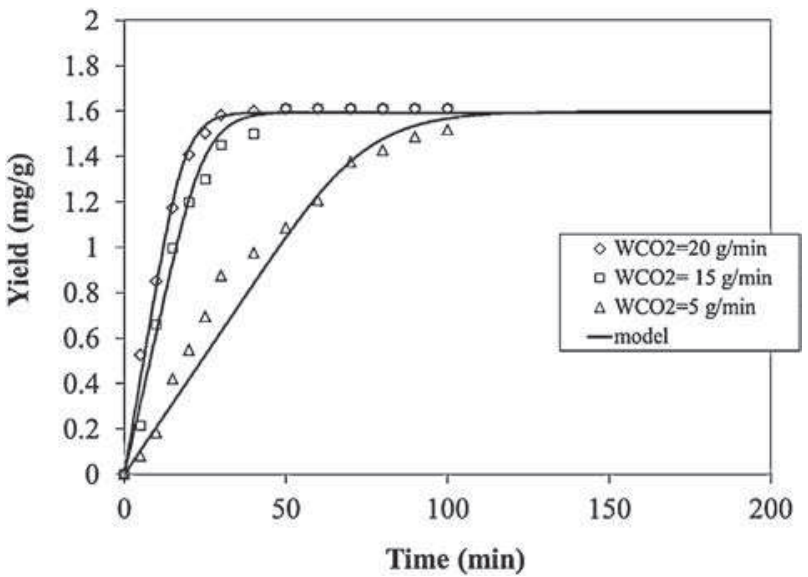

Fig. 7. T. articulata volatile oil yield for $1.5 \mathrm{~mm}$ particles size, pressure 90 bar and temperature $40^{\circ} \mathrm{C}$ at different $\mathrm{CO}_{2}$ flow rates with Reis-Vasco model (first part only).

coefficient $D_{L}$ was determined using the correlation proposed by Funazukuri [39]:

$D_{L}=1.317(\operatorname{ReSc})^{1.392}\left(\frac{D_{12}}{\varepsilon}\right)$

where

$R e=\frac{\rho_{f} u d_{p}}{\mu_{f}}$

Sc $=\frac{\mu_{f}}{\rho_{f} D_{12}}$

The binary diffusion coefficient $D_{12}$ was estimated by the Wilke-Chang equation as proposed by Funazukuri:

$D_{12}=7.410^{-12} \frac{T \sqrt{\Phi M_{\mathrm{CO}_{2}}}}{\mu_{f} V_{2 b p}^{0.6}}$

where $T$ is the temperature $(\mathrm{K}), \Phi$ is the association factor of the solvent $\left(\Phi=1\right.$ for $\left.\mathrm{CO}_{2}\right), M$ is the molar mass of the solvent and $V_{2 b p}$ is the molar volume of the solute at its normal boiling point expressed in $\mathrm{cm}^{3} / \mathrm{mol}$. As $\alpha$-pinene is a compound present in all volatile extracts, its molar volume $V_{2 b p}=178.63 \times 10^{-3} \mathrm{~m}^{3} / \mathrm{kmol}$ was used in (15) [17]. A value of $D_{12}=1.7 \times 10^{-8} \mathrm{~m}^{2} / \mathrm{s}$ was obtained for $90 \mathrm{bar}, 40^{\circ} \mathrm{C}$. Axial dispersion coefficient was found to be equal to $1.9 \times 10^{-5} \mathrm{~m}^{2} / \mathrm{s}$ and $\mathrm{Pe}=19$ in the case of $\mathrm{CO}_{2}$ flow-rate equal to $20 \mathrm{~g} / \mathrm{min}$.

In Fig. 7, experimental curves are compared with calculated yields using this model and a good agreement is observed for the three different $\mathrm{CO}_{2}$ flow-rates. Together with the qualitative analysis we have developed in the preliminary analysis, this result validates the choice of the proposed model.

\subsubsection{Use of the modeling for scaling-up the extraction process}

As we mentioned, significant axial dispersion was pointed out at laboratory scale $\left(\mathrm{Pe}=19\right.$ for $20 \mathrm{~g} / \mathrm{min} \mathrm{CO}_{2}$ flow-rate). Nevertheless its influence on the effective duration for extracting the solute is not very strong. For instance, at $20 \mathrm{~g} / \mathrm{min}$, duration for the obtaining of $90 \%$ yield is predicted at $16 \mathrm{~min}$ with the Sovova's simplified model (which neglects axial dispersion, $t_{1}$ obtained by Eq. (2)) while our modeling, which takes into account axial dispersion, indicates a value close to $20 \mathrm{~min}$. This rather moderate difference makes it possible to propose simplified scale-up by maintaining the specific flow-rate $q^{\prime}$ and the ratio height to diameter of the extractor (5 in our case). With this extrapolation rule, for instance for a 1000 fold greater vegetal mass to extract, simple computation results in a $113 \mathrm{~L}$ extractor (diameter $0.3 \mathrm{~m}$, height $1.6 \mathrm{~m}$ ) percolated by 
$240 \mathrm{~kg} / \mathrm{h}$ of $\mathrm{CO}_{2}$ (superficial velocity $10 \mathrm{~mm} / \mathrm{s}$ ) in which $90 \%$ yield is obtained after $16 \mathrm{~min}$. In this case, it can be computed that the Peclet number value is now 82 , which is more favorable than in the laboratory scale extractor (where $\mathrm{Pe}=19$ ) and indeed reinforces the validity of this simple extrapolation procedure.

\section{Conclusions}

Recovery of bioactive compounds from $T$. articulata leaves was obtained using $\mathrm{SCCO}_{2}$ extraction. For volatile compounds, optimal conditions were found to be $90 \mathrm{bar}, 40^{\circ} \mathrm{C}$, and $30 \mathrm{~min}$ duration. For non-volatile fraction, suitable conditions were found to be $1000 \mathrm{bar}, 40^{\circ} \mathrm{C}$ and $30 \mathrm{~min}$ duration. Also, quantitative assessment of the extract antioxidant power and the enrichment of antioxidant at different extraction conditions were performed. Interesting selectivity for compounds with high antioxidant activity (ABTS ${ }^{\bullet+}$ essay $(29.77 \pm 1.3,33.55 \pm 0.4$ and $40.91 \pm 0.53 \mathrm{mg} / \mathrm{L}$ ) and phenolic content $(267.90 \pm 8.06$, $102.03 \pm 4.57$ and $9.70 \pm 0.57 \mathrm{GAE} \mathrm{mg} / \mathrm{g}$ material)) were observed for SFE extracts at different pressures $(1000,280$, and 90 bar $)$, respectively. Conventional HD was tested and essential oils obtained by this technique revealed low antioxidant activity $(324.5 \pm 14.21 \mathrm{mg} / \mathrm{L})$.

Also, different chemical compositions of the extracts were found, depending on the SFE pressure extraction. Physical aspects of the low pressure supercritical extraction $\left(90 \mathrm{bar}, 40^{\circ} \mathrm{C}\right)$ were investigated and modeling of the extraction kinetics using a simplified form of the Reis-Vasco's mathematical model proved to be adequate. In our range of operating conditions, extraction of T. articulata was found to be governed by adsorption phenomenon and significant axial dispersion was pointed out. This made it possible to propose simple extrapolation procedure. It is noteworthy that productivity can be increased proportionally to $\mathrm{CO}_{2}$ flow-rate, as long as mass transfer effects remain negligible. Also, adsorption constant can be rendered more favorable by increasing the solvent power of $\mathrm{CO}_{2}$ using higher pressure but a correlative loss of selectivity is expected.

\section{References}

[1] M.J. Nicolás, M.A. Esteve, J.A. Palazón, J.J. López Hernández, Modelo sobre las preferencias de hábitat a escala local de Tetraclinis articulata (Vahl) Masters en una población del límite septentrional de su área de distribución, Anales de Biología 26 (2004) 157-167.

[2] M. Bourkhiss, M. Hnach, J. Paolini, J. Costa, A. Farah, B. Satrani, Propriétés antioxydantes et anti-inflammatoires des huiles essentielles des différentes parties de Tetraclinis articulata (Vahl), Bulletin de la Société Royale des Sciences de Liège 79 (2010) 141-154.

[3] A.B. Valenzuela, S.K. Nieto, Synthetic and natural antioxidants: food quality protectors, Grasas y Aceites 47 (1996) 186-196.

[4] A. Bernhoft, Bioactive compounds in plants - benefits and risks for man and animals, in: Proceedings from a Symposium Held at The Norwegian Academy of Science and Letters, Novus forlag, Oslo, 2010

[5] S. Martins, S.I. Mussatto, G. Martínez-Avila, J. Montañez-Saenz, C.N. Aguilar, J.A. Teixeira, Bioactive phenolic compounds: production and extraction by solidstate fermentation, Biotechnology Advances 29 (2011) 365-373.

[6] C.G. Pereira, M.A.A. Meireles, Supercritical fluid extraction of bioactive compounds: fundamentals, applications and economic perspectives, Food and Bioprocess Technology 3 (2010) 340-372.

[7] L.-E. Shi, Z.-L. Zhang, L.-Y. Xing, D.-D. Yang, Y.-P. Guo, X.-F. Guo, L.-M. Zhao, Z.-X Tang, Antioxidants extraction by supercritical $\mathrm{CO}_{2}$, J. Medicinal Plants Research 5 (2011) 300-308.

[8] E. Reverchon, I. de Marco, Supercritical fluid extraction and fractionation of natural matter, J. Supercritical Fluids 38 (2006) 146-166.

[9] E. Reverchon, J. Daghero, C. Marrone, M. Mattea, M. Poletto, Supercritical fractional extraction of fennel seed oil and essential oil: experiments and mathematical modeling, Industrial and Engineering Chemistry Research 38 (1999) 3069-3075.

[10] E. Reverchon, C. Marrone, Modeling and simulation of the supercritical $\mathrm{CO}_{2}$ extraction of vegetable oils, J. Supercritical Fluids 19 (2001) 161-175.
[11] W. Rached, H. Benamer, M. Bennaceur, A. Marouf, Screening of the antioxidant potential of some Algerian indigenous plants, J. Biological Sciences 10 (2010) 316-324.

[12] K.A. Abbas, A. Mohamed, A.S. Abdulamir, H.A. Abas, A review on supercritical fluid extraction as new analytical method, American J. Biochemistry and Biotechnology 4 (2008) 345-353.

[13] M.S.T. Barroso, G. Villanueva, A.M. Lucas, G.P. Perez, R.M.F. Vargas, G.W. Brun, E. Cassel, Supercritical fluid extraction of volatile and non-volatile compounds from Schinusmolle L, Brazilian J. Chemical Engineering 28 (2011) 305-312

[14] E. Reverchon, R. Taddeo, G. Della Porta, Extraction of sage oil by supercritical $\mathrm{CO}_{2}$ : influence of some process parameters, J. Supercritical Fluids 8 (1995) 302-309.

[15] S.A. Aleksovski, H. Sovová, Supercritical $\mathrm{CO}_{2}$ extraction of Salvia officinalis L, J. Supercritical Fluids 40 (2007) 239-245.

[16] S. Glisic, J. Ivanovic, M. Ristic, D. Skala, Extraction of sage (Salvia officinalis L.) by supercritical $\mathrm{CO}_{2}$ : kinetic data, chemical composition and selectivity of diterpenes, J. Supercritical Fluids 52 (2010) 62-70.

[17] H. Sovová, Steps of supercritical fluid extraction of natural products and their characteristic times, J. Supercritical Fluids 66 (2012) 73-79.

[18] S. Camy, J.S. Condoret, Modelling and experimental study of separators for cosolvent recovery in a supercritical extraction process, J. Supercritical Fluids 38 (2006) 51-61.

[19] S. Camy, J.S. Condoret, Dynamic modelling of a fractionation process for a liquid mixture using supercritical carbon dioxide, Chemical Engineering and Processing 40 (2001) 499-509.

[20] V.L. Singleton, R. Orthofer, R.M. Lamuela-Raventós, Analysis of total phenols and other oxidation substrates and antioxidants by means of Folin-Ciocalteu reagent, Methods in Enzymology 299 (1998) 152-178.

[21] M.S. Blois, Antioxidant determinations by the use of a stable free radical, Nature 181 (1958) 1199-1200.

[22] R. Re, N. Pellegrini, A. Proteggente, A. Pannala, M. Yang, C. Rice-Evans, Antioxidant activity applying an improved ABTS radical cation decolorization assay, Free Radical Biology and Medicine 26 (1999) 1231-1237.

[23] M. Stamenić, I. Zizovic, A. Orlović, D. Skala, Mathematical modelling of essential oil SFE on the micro-scale - classification of plant material, J. Supercritical Fluids 46 (2008) 285-292.

[24] G. Brunner, Gas Extraction: An Introduction to Fundamentals of Supercritical Fluids and the Application to Separation Processes, Springer, New York, 1994, pp. 176-250.

[25] J. da Cruz Francisco, B. Sivik, Solubility of three monoterpenes, their mixtures and eucalyptus leaf oils in dense carbon dioxide, J. Supercritical Fluids 23 (2002) $11-19$.

[26] H. Sovová, R. Komers, J. Kucera, J. Jez, Supercritical carbon dioxide extraction of caraway essential oil, Chemical Engineering Science 49 (1994) 2499-2505.

[27] P.B. Gomes, V.G. Mata, A.E. Rodrigues, Production of rose geranium oil using supercritical fluid extraction, J. Supercritical Fluids 41 (2007) 50-60.

[28] M. Akgun, N.A. Akgun, S. Dincer, Phase behaviour of essential oil components in supercritical carbon dioxide, J. Supercritical Fluids 15 (1999) 117-125.

[29] I. Zizovic, M. Stamenic, A. Orlovic, D. Skala, Supercritical carbon dioxide extraction of essential oils from plants with secretory ducts: Mathematical modelling on the micro-scale, J. Supercritical Fluids 39 (2007) 338-346.

[30] S. Ben Hadj Ahmed, R.M. Sghaier, F. Guesmi, B. Kaabi, M. Mejri, H. Attia, D. Laouini, I. Smaali, Evaluation of antileishmanial, cytotoxic and antioxidant activities of essential oils extracted from plants issued from the leishmaniasisendemic region of Sned (Tunisia), Natural Product Research: Formerly Natural Product Letters 25 (12)(2011) 1195-1201.

[31] A. Tekaya-Karoui, N. Boughalle, S. Hammami, H. Ben Jannet, Z. Mighri, Chemical composition and antifungal activity of volatile components from woody terminal branches and roots of Tetraclinis articulata (Vahl) Masters growing in Tunisia, African J. Plant Science 5 (2011) 115-122.

[32] A.F. Barrero, M.M. Herrador, P. Arteaga, J. Quilez, M. Akssira, F. Mellouki, S. Akkad, Chemical composition of the essential oil of leaves and wood of Tetraclinis articulata (Vahl) Masters, J. Essential Oil Research 17 (2005) 166-168.

[33] M. Aitigri, M. Holeman, A. Ilidrissi, M. Berrada, Contribution to the chemical study of essential oils from the twigs and wood of Tetraclinis articulata (Vahl) Masters, Plantes Médicinales et Phytothérapie 24 (1990) 36-43.

[34] S. Zrira, B. Benjilali, A. Elmrani, Chemical composition of the sawdust oil of moroccan Tetraclinis articulata (Vahl), J. Essential Oil Research 17 (2005) 96-97.

[35] J. Buhagiar, M.T.C. Podestat, P.L. Cioni, G. Flamini, L. Morelli, Essential oil composition of different parts of Tetraclinis articulata, J. Essential Oil Research 12 (2000) 29-32.

[36] M.A. Harish Nayaka, U.V. Sathisha, A.M. Dharmesh, Cytoprotective and antioxidant activity of free, conjugated and insoluble-bound phenolic acids from swallow root (Decalepis hamiltonii), Food Chemistry 119 (2010) 1307-1312.

[37] C.S. Tan, S.K. Liang, D.C. Liou, Fluid-solid mass transfer in a supercritical fluid extractor, Chemical Engineering J. 38 (1988) 17-22.

[38] E.M.C. Reis-Vasco, J.A.P. Coelho, A.M.F. Palavra, C. Marrone, E. Reverchon, Mathematical modeling and simulation of pennyroyal essential oil supercritical extraction, Chemical Engineering Science 55 (2000) 2917-2922.

[39] T. Funazukuri, C. Kong, S. Kagei, Effective axial dispersion coefficients in packed beds under supercritical conditions, J. Supercritical Fluids 13 (1998) 169-175. 